\title{
PEMBELAJARAN SEJARAH SEBAGAI UPAYA MENINGKATKAN KESADARAN SEJARAH
}

\author{
Hilya Azizah Sayuti \\ 1810111320010 \\ Program Studi Pendidikan Sejarah \\ Fakultas Keguruan dan Ilmu Pendidikan \\ Universitas Lambung Mangkurat
}

Kemajuan di berbagai bidang seperti teknologi, pendidikan, dan ekonomi yang terjadi saat ini tidak lepas dari berkembang pesatnya ilmu pengetahuan dari masa ke masa. Era globalisasi seperti sekarang ini sangat berkaitan erat dengan kemajuan teknologi yang berjalan beriringan dengan kemajuan-kemajuan di bidang lainnya. Menurut Grew dalam Lestari (2018: 94-100) globalisasi secara luas dipahami sebagai peregangan kegiatan sosial, politik, dan ekonomi lintas batas sehingga kejadian, keputusan, dan kegiatan yang berlangsung di suatu tempat atau suatu wilayah memiliki arti penting bagi masyarakat keseluruhan. Globalisasi juga tidak dapat dipungkiri menjadikan perkembangan kebudayaan di seluruh dunia menjadi kian pesat akibat saling berbaurnya kebudayaan suatu negara dengan kebudayaan negara lainnya. Dalam hal ini para generasi muda bahkan masyarakat menjadi lebih dekat dengan modernisasi sehingga banyak melupakan tradisi, sejarah, maupun lokalitas bangsanya sendiri.

Menurunnya tingkat kesadaran sejarah berakibat pada hilangnya identitas atau jati diri bangsa serta norma dan nilai yang telah ada sehingga terjadi krisis multi dimensi yang menyebabkan menurunnya moral bangsa. Pendidikan sejarah dalam era globalisasi diperlukan agar bangsa Indonesia memiliki kepribadian bangsa dan kesadaran sejarah yang kuat serta dapat terlibat aktif (Putro, 2012: 207-2016). Menurut Soedjatmoko dalam Putro (2012: 207-216) kesadaran sejarah sebagai bentuk "rasa hayat historis" memiliki posisi fundamental bagi keberadaan suatu bangsa. Sedangkan menurut Widja dalam Novandri (2013: 4) kesadaran sejarah adalah refleksi sikap yang bersumber pada kondisi kejiwaan yang menunjukan tingkat penghayatan, pada makna serta hakikat sejarah. Kesadaran sejarah berhubungan erat dengan kecenderungan untuk bersikap dan bertindak. Ruslan Abdulgani dalam Novrandi (2013: 4) mengatakan bahwa kesadaran sejarah adalah mental atitude, suatu sikap kejiwaan sebagai kekuatan untuk aktif berperan dalam proses dinamika sejarah. 
Salah satu usaha nyata untuk mengenalkan dan mempelajari sejarah bangsa Indonesia adalah melalui pendidikan dan pembelajaran sejarah (Novandri, 2013: 4). Pembelajaran sejarah adalah interaksi antara peserta didik dengan pendidik dalam aktivitas belajar mengajar yang mengkaji tentang peristiwa masa lampau yang membawa pengaruh besar untuk masa kini dan masa yang akan datang. Pembelajaran sejarah di sekolah mempunyai tujuan yaitu menanamkan semangat kebangsaan, cinta tanah air, bangsa dan negara serta sadar untuk menjawab untuk apa dia dilahirkan. Pembelajaran sejarah salah satu unsur utama dalam pendidikan politik bangsa. Lebih jauh lagi pengajaran sejarah merupakan salah satu unsur utama dalam pendidikan politik bangsa. Lebih jauh lagi pengajaran sejarah merupakan sumber inspirasi terhadap hubungan antar bangsa dan negara. Dengan mempelajari sejarah diharapkan siswa akan mempunyai kesadaran bahwa ia merupakan bagian dari masyarakat negara dan dunia sehingga akan berusaha menjadi generasi muda yang lebih bijaksana.

\section{REFERENSI}

Lestari, S. (2018). Peran teknologi dalam pendidikan di era globalisasi. EDURELIGIA: Jurnal Pendidikan Agama Islam, 2(2), 94-100.

Novandri, B. (2013). Pengaruh Pemanfaatan Sumber Sejarah Lokal Daerah Sekitar Kota Tegal Terhadap Kesadaran Sejarah Siswa SMA Negeri Se-Kota Tegal (Doctoral dissertation, Universitas Negeri Semarang).

Putro, H. P. N. (2012). Model Pembelajaran Sejarah Untuk Meningkatkan Kesadaran Sejarah Melalui Pendekatan Inkuiri. Paramita: Historical Studies Journal, 22(2). 